\title{
FASILITAS PELATIHAN DAN KOMUNITAS DESAIN GRAFIS
}

\author{
Filbert Uriel Sulaiman ${ }^{1)}$, Suwardana Winata ${ }^{2)}$ \\ 1) Program Studi S1 Arsitektur, Fakultas Teknik, Universitas Tarumanagara, filbert.uriel96@gmail.com \\ 2) Program Studi S1 Arsitektur, Fakultas Teknik, Universitas Tarumanagara, danarsitek@gmail.com \\ Masuk: 10-01-2020, revisi: 28-01-2020, diterima untuk diterbitkan: 09-05-2020 (doi: 10.24912/stupa.v2i1.6811)
}

\begin{abstract}
Abstrak
Kecamatan Bungur, yang terletak di distrik Senen, Jakarta Pusat, terkenal sebagai daerah percetakan. Bungur memiliki berbagai jenis layanan pencetakan, mulai dari pencetakan digital, cetak offset, dan layanan finishing (emboss, binding, cutting, dll). Oleh karena itu banyak pekerja terampil dipekerjakan untuk bekerja di bidang percetakan. Pekerja yang terampil atau tidak terampil dalam layanan pencetakan adalah orang-orang yang mengandalkan tenaga fisik dan cenderung bekerja lebih lama daripada pekerja yang berpendidikan. Kurangnya interaksi dan ketegangan di tempat kerja setelah waktu yang lama dapat menyebabkan stres yang mengarah pada penyakit lain. Namun, masalah ini dapat diselesaikan dengan interaksi informal yang terpisah dari tempat kerja mereka dan rumah dapat mengurangi stres tersebut. Tetapi, jam kerja yang panjang menghasilkan kesempatan minimal bagi para pekerja ini untuk melakukan interaksi sosial di luar tempat kerja atau rumah mereka. Akibatnya, fasilitas pelatihan ini dirancang untuk menjadi tempat bagi pekerja terampil dan tidak terampil untuk berinteraksi sosial antara tempat kerja dan rumah mereka. Bukan hanya tempat untuk melakukan interaksi sosial, tetapi proyek ini juga bertujuan untuk menjadi tempat bagi warga Kecamatan Bungur untuk mengembangkan keterampilan mereka dalam desain grafis. Sebagai tempat interaksi, bangunan dirancang memiliki ruang terbuka lebar bagi siapa saja di lantai dasar yang terbuka dan menjadi satu dengan lantai dasar. Kemudian fasilitas pelatihan dan galeri melayang di atasnya dengan dukungan kolom. Pemisahan antara fasilitas pelatihan, galeri, dan ruang terbuka di bawahnya bertujuan untuk memenuhi kebutuhan masing-masing program.
\end{abstract}

\section{Kata kunci: bungur; pelatihan; tenaga kerja; terampil; tidak terampil}

\begin{abstract}
Bungur subdistrict, located in Senen district, Central Jakarta, is famous as a printing area. Bungur has various types of printing services starting from digital printing, offset printing, and finishing services (emboss, binding, cutting, etc). There are many skilled workers are hired to work in the printing services. Skilled or unskilled workers in printing services are people who rely on physical labour and tend to work longer than educated workers. The lack of interaction and tension in the workplace after a long period can cause stress which leads to other diseases. However, the stress can be solved by having an informal interaction apart from their workplace and home. In the other hand, long working hours have reduced opportunities for these workers to have an informal social interaction. As a respond to the problem, this training facility design as a place for skilled and unskilled workers to have social interaction apart from their workplace and home. This project also aims to be a place for residents of Bungur Subdistrict to develop their skills in graphic design. To reach the goals, the design has a wide-open space for anyone on the basement floor which is open and becomes into one virtually with the ground floor. Above the open space there are training facility and gallery which have separated circulation. The separation between the training facilities, gallery, and the open space under it aims to fulfil the needs of each program.
\end{abstract}

Keywords: bungur; interaction; skilled; training; unskilled; workers 


\section{PENDAHULUAN}

Kelurahan Bungur yang terletak di kecamatan Senen, merupakan kawasan industri percetakan dan perumahan. Pada kawasan ini berbagai tahap jasa percetakan terjadi seperti suplai kertas, proses print digital maupn offset, dan berbagai proses finishing. Aktivitas yang terjadi di kawasan ini di dominasi oleh aktivitas percetakan yang dilakukan hingga larut malam. Kelurahan ini berisi warga yang bervariasi seperti pelajar, ibu rumah tangga, pedagang, karyawan, dan salah satunya adalah buruh yang menjadi karakter kawasan percetakan ini.

Sebagai tenaga kerja percetakan, maka tenaga kerja yang ada merupakan tenaga kerja terampil. Dengan mengandalkan keterampilan maka buruh percetakan di Bungur harus bekerja terusmenerus hingga larut malam saat mendapat pesanan. Namun ketika tidak banyak pesanan yang diminta maka tidak banyak yang dilakukan dan harus tetap berada di tempat kerja dan menunggu. Aktivitas tersebut tidak banyak memberi kesempatan untuk memiliki hubungan sosial di luar tempat kerja maupun lingkungan rumah.

Sebagai buruh percetakan tidak banyak keterampilah yang dapat di kembangkan. Tidak ada tingkatan pangkat maupun kenaikan gaji yang jelas sehingga tidak dapat banyak berkembang dalam pendapatan. Kemudian dilihat dari aktivitasnya yang tidak memiliki variasi gerakan dan bersifat repetitif sehingga menghasilkan tekanan pada beberapa bagian tubuh. Kondisi tersebut berpotensi menjadi stressor (penyebab stres).

Fasilitas pelatihan ini di rancang untuk menjadi tempat bagi tenaga kerja terampil maupun yang tidak terdidik dan terampil untuk berkembang di dalam komunitas desain grafis. Selain menjadi tempat berkembang dalam keterampilan desain grafis, proyek ini bertujuan untuk menjadi tempat bagi warga kelurahan Bungur untuk memiliki jenis interaksi selain di tempat kerja dan tempat tinggal atau di sebut sebagai tempat ketiga (third place). Untuk mewujudkan tempat yang berfungsi sebagai tempat berinteraksi tersebut maka di dalam desain yang terletak diantara tempat kerja dan tempat tinggal, di buatlah ruang terbuka untuk siapa saja pada lantai basement yang terbuka dan menjadi satu dengan lantai dasarnya dan fasilitas pelatihan serta galeri berada mengambang di atasnya dengan topangan kolom- kolom.

Dalam fasilitas pelatihan ini, warga bungur di tawarkan untuk mengikuti pelatihan mengenai dasar-dasar desain grafis melalui teknik membuat cetakan dengan cara manual ( teknik printmaking). Di dalam teknik printmaking pelatihan di bagi menjadi 2 jenis yaitu teknik stone lithography, dan relief printing. Teknik relief printing merupakan teknik cukil yang di dalamnya dapat di bagi lagi berdasarkan medianya yaitu blok kayu dan lembaran linoleum. Selain pelatihan desain grafis melalui cara manual, pelatihan dengan cara digital juga di tawarkan pada program. Pelatihan desain grafis dengan cara digital berupa workshop lasercut, $3 d$ printing, dan kelas desain grafis.

\section{KAJIAN LITERATUR}

\section{Open Architecture}

Open Architecture, merupakan The Third Place bagi masyarakat kota, yang berfungsi sebagai ruang antara, ruang yang bukan tempat tinggal, dan juga bukan merupakan tempat kerja. The Third Place adalah sebuah program yang akan membantu masyarakat kota agar bersifat humanis, terbuka, dinamis, dan produktif. Open architecture merupakan sistem yang terbuka dan mampu beradaptasi dengan kepentingan terpilih. Konflik - konflik yang terjadi dari masyarakat kota dapat dipecahkan atau dilakukan pendekatan melalui rangkaian pendekatan desain dan juga strategi perancangan. Esensi dari third place tidak kalah penting dari kedua tempat sebelumnya (first dan second place) dan ketiganya membutuhkan keseimbangan bagi tiap individu.

Seseorang memiliki kesediaan murni untuk berbicara dan beraktivitas dengan orang lain, kesediaan itu adalah alasan tepat untuk orang- orang berkumpul tanpa tujuan lain dan tidak lebih tinggi atau lebih rendah selain untuk kegembiraan, antusiasme, dan kelegaan ketika 
melibatkan kepribadian mereka di luar konteks tujuan, tugas, atau peran. Alasan tersebut memungkinkan mereka untuk menjadi diri mereka sepenuhnya. Dan demi menjadi diri mereka sepenuhnya, maka mereka rela untuk melepaskan status sosial mereka. Third place dapat memberikan wadah bagi individu untuk berkumpul tanpa tujuan lain selain kegembiraan, antusiasme, dan kelegaan.

Menurut Oldenburg(1999) third place terdiri dari 8 karakteristik, yaitu:

\begin{tabular}{|c|c|}
\hline Karakter & Definisi \\
\hline $\begin{array}{l}\text { Neutral } \\
\text { Ground }\end{array}$ & $\begin{array}{l}\text { Semua orang dapat datang dan pergi sesuka mereka tanpa } \\
\text { harus ada yang menjadi tuan rumah dan mereka merasa } \\
\text { nyaman seperti berada di rumah. }\end{array}$ \\
\hline Leveler & $\begin{array}{l}\text { Dimana status sosial masyarakat tidak dipedulikan sehingga } \\
\text { dapat menjadi diri mereka sepenuhnya ketika berinteraksi } \\
\text { dengan orang lain. }\end{array}$ \\
\hline $\begin{array}{l}\text { Conversation } \\
\text { is the main } \\
\text { activity }\end{array}$ & $\begin{array}{l}\text { Percakapan merupakan poin utama, sehingga pengetahuan } \\
\text { dan kemampuan berkomunikasi akan selalu di latih untuk } \\
\text { menciptakan suasana yang hidup. }\end{array}$ \\
\hline $\begin{array}{l}\text { Third place } \\
\text { are } \\
\text { accessible }\end{array}$ & $\begin{array}{l}\text { Tempat yang bebas dikunjungi kapanpun dan dapat dengan } \\
\text { mudah dicapai. Sehingga memiliki jaminan kenalan } \\
\text { (seorang/lebih) berada di sana. }\end{array}$ \\
\hline Regulars & $\begin{array}{l}\text { Ruang dalam third place haruslah menjadi bagian dari } \\
\text { sekumpulan orang tertentu dan merekalah yang memberi } \\
\text { karakter di tempat tersebut. }\end{array}$ \\
\hline $\begin{array}{l}\text { Low profile, } \\
\text { physically } \\
\text { plain }\end{array}$ & $\begin{array}{l}\text { Third Place memiliki profil yang sederhana dan tidak elegan } \\
\text { karena tidak bertujuan untuk menarik pelanggan asing, dan } \\
\text { mencegah pretensi di antara pelanggan. }\end{array}$ \\
\hline $\begin{array}{l}\text { The mood is } \\
\text { playful }\end{array}$ & $\begin{array}{l}\text { Suasana yang selalu ada di Third Place yaitu menyenangkan, } \\
\text { hal ini akan terus membuat percakapan bertahan lama dan } \\
\text { menimbulkan rasa ingin kembali dan mengalami } \\
\text { pengalaman yang menyenangkan }\end{array}$ \\
\hline $\begin{array}{lr}\text { A } & \text { home } \\
\text { away } & \text { from } \\
\text { home } & \end{array}$ & $\begin{array}{l}\text { Meskipun memiliki perbedaan yang jelas pada setting } \\
\text { dengan rumah, tetapi memiliki kesamaan dalam } \\
\text { kenyamanan psikologi dan dukungan yang di perluas Third } \\
\text { place. }\end{array}$ \\
\hline
\end{tabular}

Menurut Oldenburg (1999) third place merupakan tempat netral yang berfungsi untuk menghadirkan kondisi kesetaraan sosial bagi siapapun yang datang. Di dalam tempat-tempat ini, percakapan adalah aktivitas utama dan instrumen utama untuk menampilkan dan mengapresiasi kepribadian manusia. Jika tempat lain terlihat megah dan hanya dapat digunakan oleh kalangan tertentu, maka Third Place tidak berpenampilan megah atau mencolok sehingga diterima apa adanya selain itu biasanya buka di luar jam kerja, dan juga di waktu kerja. Karakter tempat ketiga sebagian besar ditentukan oleh pelanggan regulernya dan ditandai oleh suasana hati yang menyenangkan. Meskipun bentuk fisik yang sangat berbeda dari rumah, Third Place sangat mirip dengan rumah dalam kenyamanan psikologis dan dukungan yang diperluas. Seperti itulah karakteristik tempat ketiga yang tampaknya universal dan esensial bagi kehidupan publik informal yang vital. 


\section{Desain Grafis}

Pada pendefinisian dari desain grafis diambil berdasarkan definisi dari masing- masing kata itu sendiri yaitu desain dan grafis. Proses definisi dari tiap kata itu sendiri dimulai dari pengambilan bahasa inggrisnya dan kemudian di terjemahkan kemudian ditentukan maksud dan kebutuhannya.

Design : A plan or drawing produced to show the look and function or workings of a building, garment, or other object before it is built or made.

Desain yaitu rencana atau gambar yang di hasilkan untuk memperlihatkan tampilan dan fungsi dari bangunan, garmen, atau objek lain sebelum dibangun atau dibuat. Dengan demikian dalam desain terdapat rencana yang disusun sebelum membuat sesuatu. Untuk memulai desain maka membutuhkan pengetahuan dasar yang dapat dipelajari dari pengalaman, proses belajar, atau di ajarkan.

Graphic: Relating to visual art, especially involving drawing, engraving, or lettering.

Grafis berkaitan dengan seni visual, khususnya melibatkan gambar, ukiran, atau bentuk tulisan.

Seni visual merupakan seni yang berkaitan dengan penglihatan, sehingga tujuannya adalah untuk dilihat. Karena bertujuan untuk dilihat maka membutuhkan media fisik untuk dilihat. Media grafis yang digunakan dapat berupa digital maupun analog. Media digital merupakan media yang dapat disebarkan melalui internet atau jaringan komputer. Sedangkan media analog merupakan media yang tidak menggunakan teknologi komputer yang sehingga kontras dengan digital.

\section{Definisi Desain Gafis}

Dari kedua pengertian tersebut maka desain grafis adalah seni visual yang membutuhkan proses perencanaan atau penyusunan yang memiliki tujuan akhir untuk diperlihatkan (dipamerkan). Dalam konteks kelurahan Bungur yang memiliki tenaga kerja yang terampil dan tujuan proyek untuk mengebangkan kemampuan mereka, maka proses belajar yang diterapkan dalam proyek adalah proses pelatihan yang menggunakan media digital.

\section{Tinjauan Fasilitas Pelatihan}

Fasilitas pelatihan merupakan sesuatu yang memberikan kemudahan dalam melakukan tujuan tertentu dan dapat berupa peralatan, tempat, atau lainnya. Dengan tujuan untuk mengenal desain grafis maka fasilitas adalah tempat yang menyediakan berbagai alat yang dapat mendukung proses pelatihan desain grafis melalui media analog dan media digital. Di dalam fasilitas desain grafis ini terdapat dua teknik pelatihan desain grafis yaitu menggunakan teknik analog dan teknik digital. Di dalam teknik analog terbagi menjadi tiga bagian yaitu lithography, metal etching, dan relief printing. Sedangkan pada teknik digital, pelatihan yang diberikan adalah kelas desain grafis, $3 d$ printng, dan lasercut.

\section{Media Analog Desain Grafis}

Proses pelatihan desain grafis menggunakan media analog dapat menggunakan berbagai teknik. Teknik printmaking atau pembuatan cetakan tradisional merupakan salah satu cara yang diterapkan pada proyek. Teknik tersebut digunakan karena memiliki beberapa aspek yang menjadi dasar dari mesin percetakan yang biasa dioperasikan oleh pekerja percetakan di Bungur. 
Di dalam printmaking terdapat berbagai teknik pembuatan cetakan, yang diterapkan dalam proyek adalah :

\section{a. Relief Print}

Merupakan teknik yang dapat digunakan tanpa bantuan alat atau dapat di lakukan hanya menggunakan tangan. Di dalam teknik ini jenis cetakan yang di buat adalah:

- Linocut (cukil linoleum)

Proses mencukil lembaran linoleum untuk menghasilkan cetakan dimana permukaan yang tidak tercukil merupakan tempat bagi cat untuk menempel.

- Wood Engraving (cukil kayu)

Proses mencukil balok kayu untuk menghasilkan cetakan dimana permukaan yang tidak tercukil merupakan tempat bagi cat untuk menempel.

Dalam kedua teknik relief print gambar yang dihasilkan dapat berupa susunan komposisi bagian yang tercukil dan yang tidak.

\section{b. Metal Etching}

Merupakan teknik yang menggunakan plat besi sebagai cetakan. Dalam proses menjadi cetakan, plat besi menjalani beberapa proses pelapisan dan pengikisan kimia untuk menciptakan permukaan yang terkikis (etch) dan tetap datar. Plat yang digunakan adalah plat metal krom atau aluminium.

\section{c. Lithography}

Merupakan teknik pembuatan cetakan yang menggunakan balok batu gamping (limestone). Dalam proses ini balok batu di gambar kemudian dilapisi oleh beberapa bahan kimia untuk membedakan mana bagian yang menyerap air dan menyerap tinta atau cat. Teknik ini merupakan dasar yang digunakan dalam mesin offset printing yang ada di percetakan Bungur.

\section{Media Digital Desain Grafis}

Media digital yang diterapkan dalam proyek adalah teori dasar desain grafis, $3 d$ print dan lasercut. Pada teori dasar desain grafis yang dilatih merupakan pembuatan tipografi, teori warna, dan dasar- dasar penggunaan software Adobe di komputer. Pada $3 d$ print dan lasercut, pelatihan yang di terapkan adalah pembuatan produk yang dapat dihasilkan dari kedua alat dan pengoperasian alat $3 d$ printing dan lasercut

\section{METODE}

Metode atau Method merupakan cara untuk memastikan sesuatu berjalan sesuai rencana secara terstruktur hingga dapat terselesaikan atau selesai.

\section{Metode Observasi}

Metode observasi adalah menggambarkan apa yang terjadi, siapa atau apa yang terlibat, kapan dan di mana hal itu terjadi, bagaimana mereka terjadi, dan mengapa hal terjadi seperti yang mereka lakukan di situasi tertentu. Metodologi observasi partisipan digunakan untuk mempelajari proses, hubungan antar individu-individu, individu dengan peristiwa, organisasi secara kontinuitas dari waktu ke waktu, dan pola, sosial budaya yang terjadi dimana individu tersebut berada.

\section{Metode Fungsionalisme}

Teori ini didasarkan pada mekanismesosial dalam masyarakat dan prinsip-prinsip organisasi di dalamnya.Pengembangan ini disebut juga struktural-fungsionalisme. Dalam pandangan ini, masyarakat tersusun atas bagian-bagian seperti misalnya rumah sakit, sekolah, pertanian, dan seterusnya yang terbagi berdasarkan fungsinya. Masyarakat ibarat sebuah organisme, makhluk 
hidup yang bisa sehat atau sakit. la sehat jika bagian-bagian dari dirinya (kelompok fungsional, individu) memiliki kebersamaan satu sama lain. Jika ada bagiannya yang tidak lagi menyatu secara kolektif, maka kesehatan dari masyarakat tersebut terancam, atausakit.Fungsionalisme melihat masyarakat sebagai sebuah sistem daribeberapa bagian yang saling berhubungan satu dengan lainnya. Satubagian tidak bisa dipahami terpisah dari keseluruhan. Dengan demikian, dalam perspektif fungsionalisme ada beberapa persyaratan atau kebutuhan fungsional yang harus dipenuhi agar sebuah sistem sosial bisa bertahan. Parsons kemudian mengembangkan apa yang dikenal sebagai imperatif-imperatif fungsional agar sebuah sistem bisa bertahan.Imperatif-imperatif tersebut adalah Adaptation, Goal attainment, Integration, Latency. Adaptasi, merupakan fungsi yang sangat penting, karena dalam hal ini sistem harus dapat beradaptasi dengan cara menanggulangi situasi eksternal yang urgent dan sistem juga harus bisa menyesuaikan diri dengan lingkungan. Goal attainment atau pencapaian tujuan juga sangat penting, dimana sistem harus bisa mendefinisikan dan mencapai tujuan utamanya. Integrasi, artinya sistem harus mampu mengatur dan menjaga antara hubungan bagian-bagian yang menjadi komponennya,selain itu mengatur dan mengelola ketiga fungsi lainnya (adaptasi, goalattainment dan latensi). Sedangkan latensi, berarti bahwa sistem harus mampu berfungsi sebagai pemelihara pola.

\section{DISKUSI DAN HASIL}

Bangunan yang terletak di kelurahan Bungur ini bertujuan untuk memberikan tempat bagi warga Bungur untuk dapat memiliki interaksi sosial di luar tempat kerja dan tempat tinggal mereka. Dan tidak hanya sebagai tempat untuk berinteraksi tetapi menjadi tempat dimana warga Bungur dapat mengembangkan keterampilan mereka dalam bidang Desain Grafis. Maka dari itu bangunan ini akan menjadi tempat dimana warga bungur memiliki interaki dalam komunitas desain grafis.

\section{Pembentukan massa}

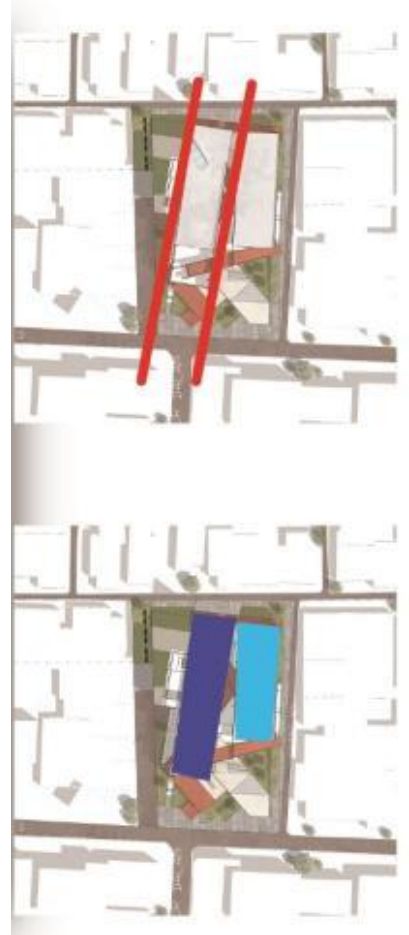

Massa bangunan utama di miringkan ke kanan (diagonal dari barat daya- timur laut).

Bertujuan untuk mem beri jarak pada bangunan perumahan di sisi utara sehingga tidak terblok oleh bayangan massa bangunan.

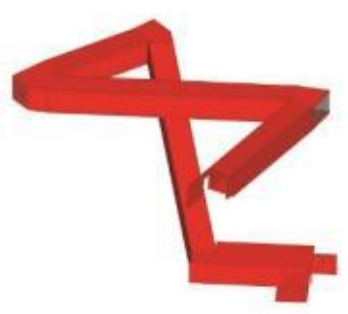

Kedua bagian dari massa yang terpisah di satukan dengan galeri yang menerus dan berliku.

Galeri memiliki bentuk yang berbeda dari massa lainnya, tujuannya adalah memberi sorotan dan memamerkan hasil workshop yang telah dibuat. $\mathrm{Hal}$ tersebut merupakan tujuan dari desain grafis yang hasilnya desainnya kan di pamerkan kepada akan di pamerkan kepada publik.

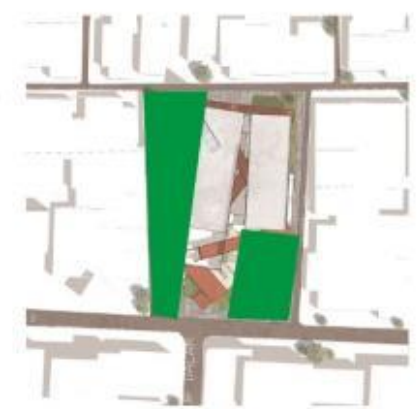

Area tapak yang terbuka akibat bentuk masa yang di miringkan dimanfaatkan untuk menjadi taman dan tempat masuk menuju bagian bawah bangunan. massa bangunan terdiri dari 2 yaitu massa ban gunan utama yang beris workshop lithograpy. metal etching, relief printing. 3d dan lasercut print. kelas desain grafis. dan artshop.

Massa bangunan lainnya adalah auditorium sebagai penunjang kegia tan meet up. presentasi. atau seminar. 
Massa bangunan terbentuk dari adaptasi lingkungan dan juga kebutuhan akan fungsi utama bangunan.

a. Program Ruang dan Lingkungan.

Dengan program bangunan yang memiliki ketinggian bangunan 4 lantai maka pada pembentukan massa bangunan yang pertama diperhatikan adalah bagaimana bangunan tersebut tidak menutupi bangunan sekitarnya dengan bayangan massa bangunan.

b. Pengelompokan Program.

Kemudian dari program ruang yang ada massa di bagi menjadi 2, massa pertama merupakan yang berkaitan dengan pelatihan dan yang kedua sebagai auditorium untuk penunjang kegiatan meet up, presentasi, atau seminar. Pembagian ini bercerita tentang di dalam desain grafis terdapat pengelompokan konten atau isi dari sebuah proyek untuk memudahkan pembaca untuk mengerti konten tersebut.

c. Fungsi Galeri.

d. Kedua massa bangunan di ikat dengan galeri yang memiliki bentuk yang berbeda dari bentuk massa bangunan lainnya yaitu ramp yang menerus dari lantai dasar hingga lantai teratas. Bentuk yang berbeda didasarkan fungsi galeri sebagai tempat akhir dari proses desain grafis yaitu untuk ditunjukan atau dipamerkan kepada orang lain sehingga memiliki bentuk yang berbeda.

e. Ruang Terbuka.

Pada pembentukan massa secara vertikal maka lantai dasar di buka dan menjadi satu dengan lantai basement menghasilkan ruang publik terbuka berupa plaza dan cafetaria yang dapat di akses siapa saja. Pada lantai dasar yang bebas dari massa bangunan di buat tamantaman bagi warga Bungur untuk dapat berinteraksi, bermain, dan terlindung dari lalu lalang kendaraan.
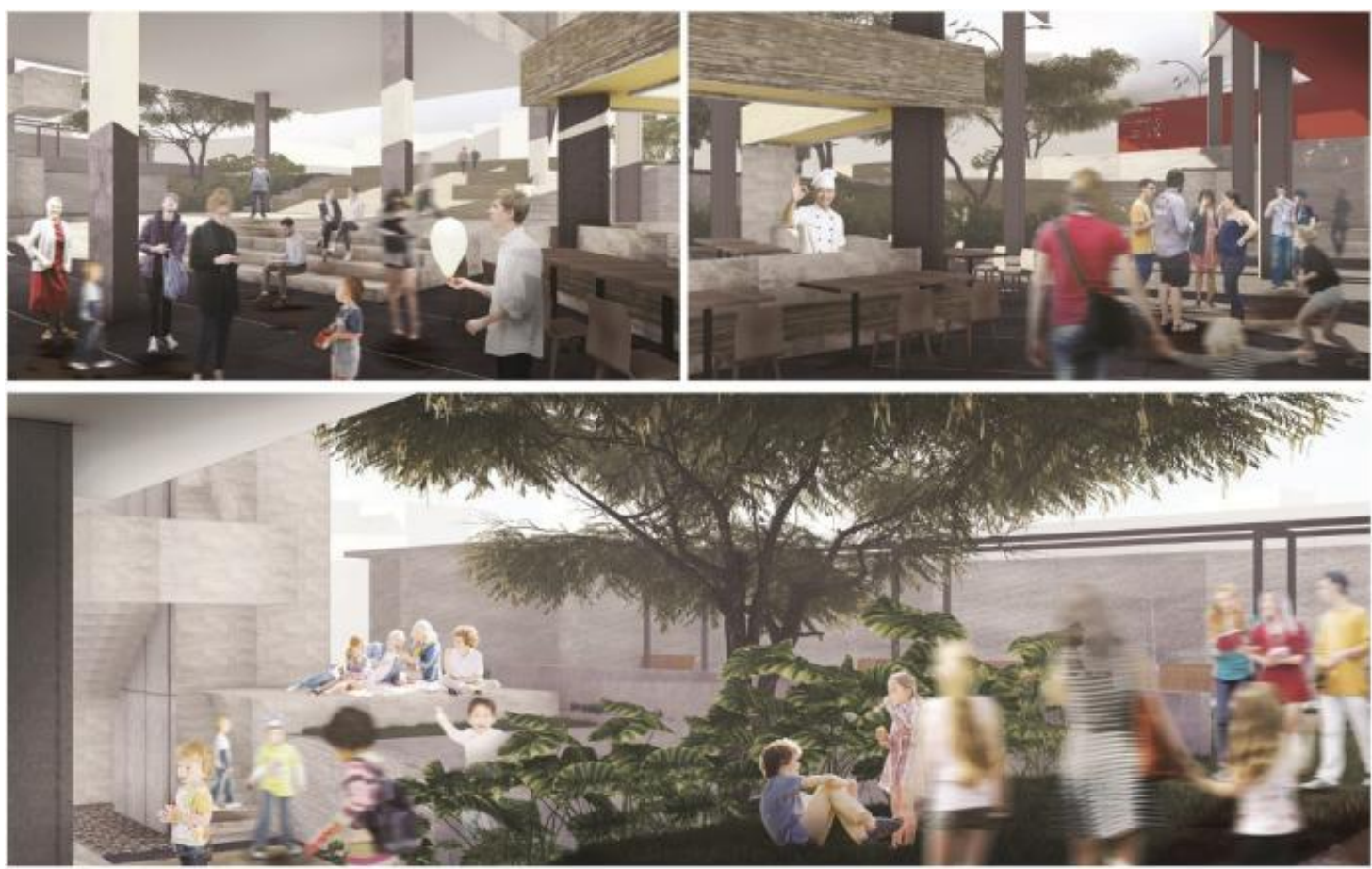

Gambar 2. Perspektif Lantai Basement

Sumber: Penulis, 2019 


\section{Fasad}

Fasad pada bangunan di desain sebagai ekspresi dari fungsi yaitu sebagai fasilitas pelatihan desain grafis. Pada tampak samping kiri terdapat dinding yang memiliki gambar peta dari kawasan Bungur yang di ukir. Ukiran tersebut di desain untuk mengekspresikan program workshop relief printing atau teknik cukil kayu dan linoleum. Penggunaan bentuk peta dalam fasad samping kiri bercerita tentang bagaimana interaksi yang biasa dilakukan di kawasan Bungur berlokasi di jalan- jalan tempat mereka tinggal maupun berkerja. Kemudian terdapat juga second skin di bagian yang berjendela. Second skin yang diterapkan berupa perforated metal yang memiliki tulisan untuk menonjolkan bidang tipografi dalam disain grafis.

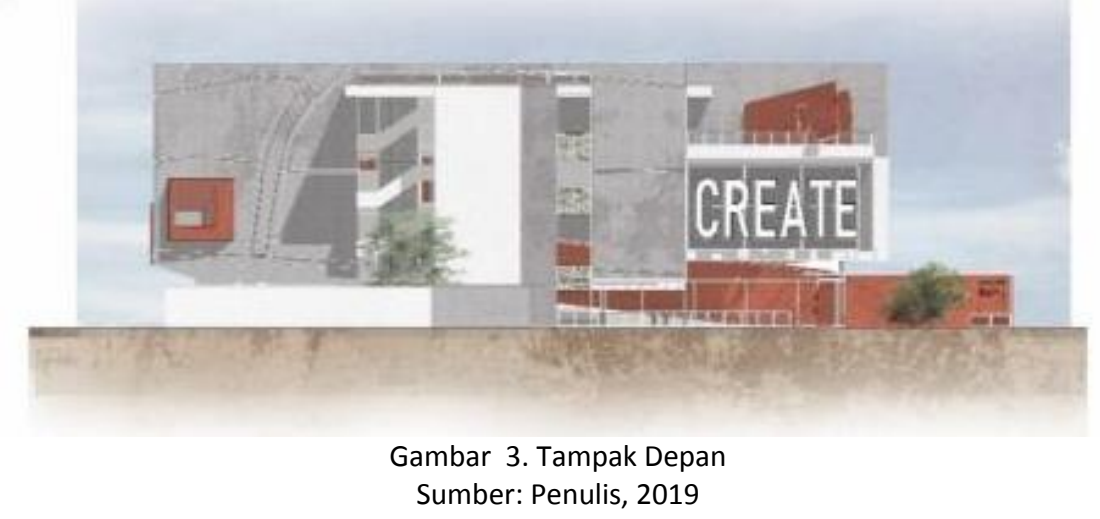

Pada bagian fasad depan terdapat jendela yang memiliki sirip- sirip vertikal pada kusennya yang terlihat seperti di gantung sehingga membatasi sinar matahari yang masuk. Bentuk siripsirip tersebut juga bercerita tentang program workshop analog printing tepatnya saat proses pengeringan kertas yang di gantung setelah diberi cat.

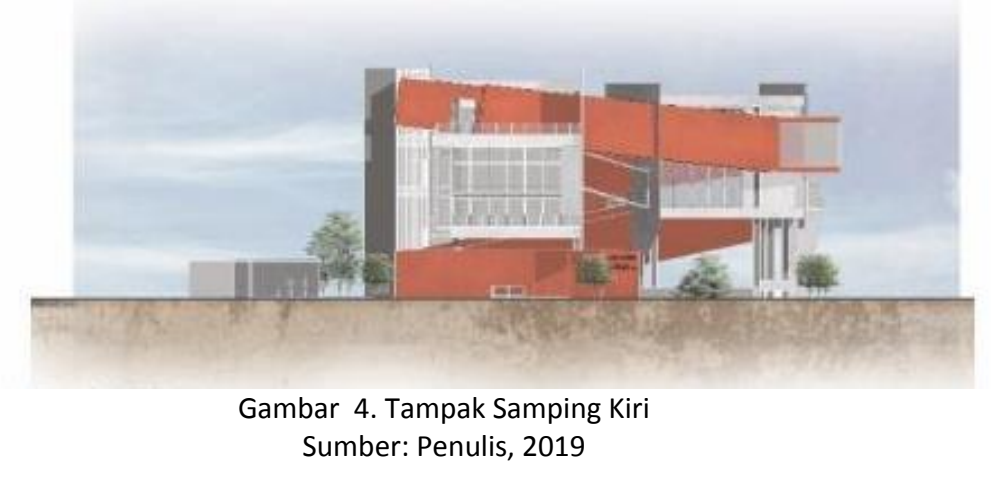

Repetisi di lakukan di beberapa bagian fasad, salah satunya bentuk dinding berukirkan peta kelurahan Bungur di terapkan pada bagian fasad kanan. Kemudian penggunaan warna merah terus di gunakan pada bagian galeri yang menerus dari lantai dasar hingga lantai 4, sehingga setiap fasad memiliki bentuk diagonal yang berwarna merah.
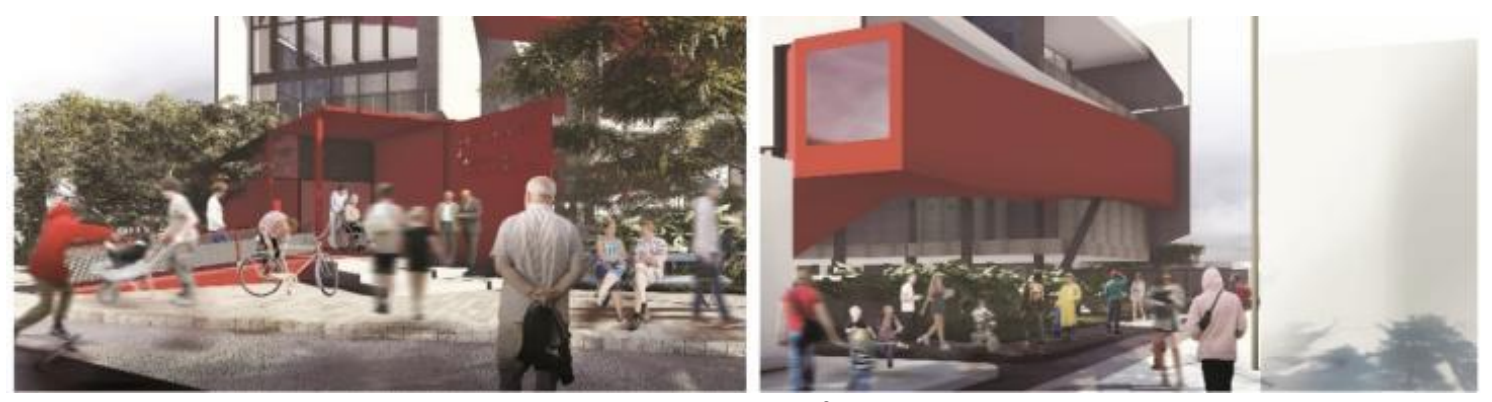

Gambar 5. Perspektif Exterior

Sumber: Penulis, 2019 


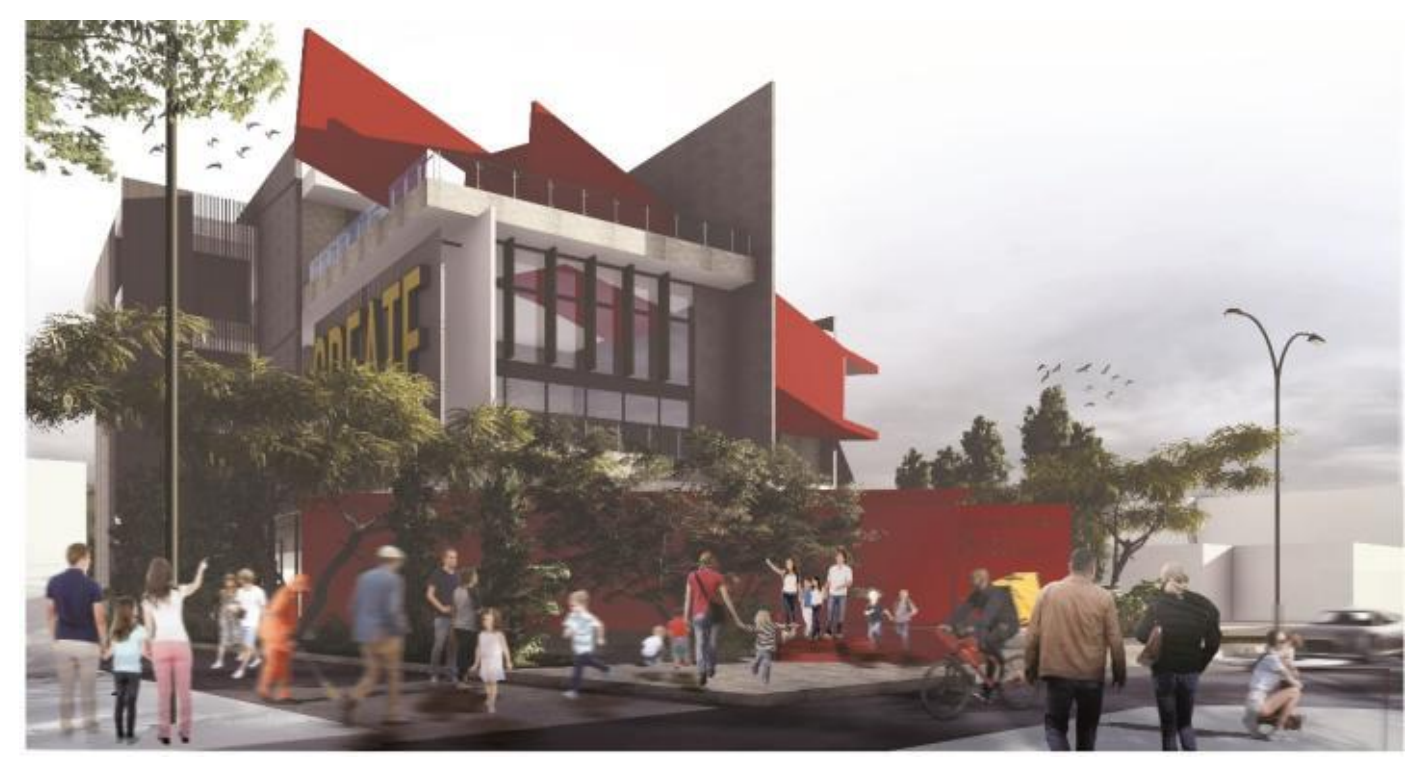

Gambar 6. Perspektif Exterior

Sumber: Penulis, 2019

\section{Struktur}

Proyek Fasilitas Pelatihan dan Komunitas Desain Grafis ini menggnakan sistem struktur rangka baja. Penggunaan baja bertujuan untuk memiliki ketebalan balok yang lebih tipis sehingga menghasilkan ketinggian langit-langit ruangan yang lebih tinggi dibandingkan dengan penggunaan sistem balok beton. Ketinggian langit- langit ruangan bertujuan untuk menciptakan sirkulasi udara yang lebih leluasa. Selain itu pada beberapa ruangan dengan program fasilitias pelatihan seperti workshop lithography, ketinggian ceiling dibutuhkan karena penggunaan bahan kimia dengan bau yang tidak aman bagi pengguna ruang. Dengan demikian ketinggian ceiling memberi ruang dalam sistem pembuangan udara.

Pada struktur galeri menggunakan sistem balok baja space frame dengan topangan kolomkolom yang juga menopang kedua massa bangunan yang di lewati oleh jalur struktur galeri. Dengan demikian kolom- kolom memiliki dua fungsi yaitu menopang plat lantai serta dinding masing- masing masa bangunan dan juga menopang struktur galeri. Kerangka utama pada galeri dibuat dengan menggunakan baja IWF.

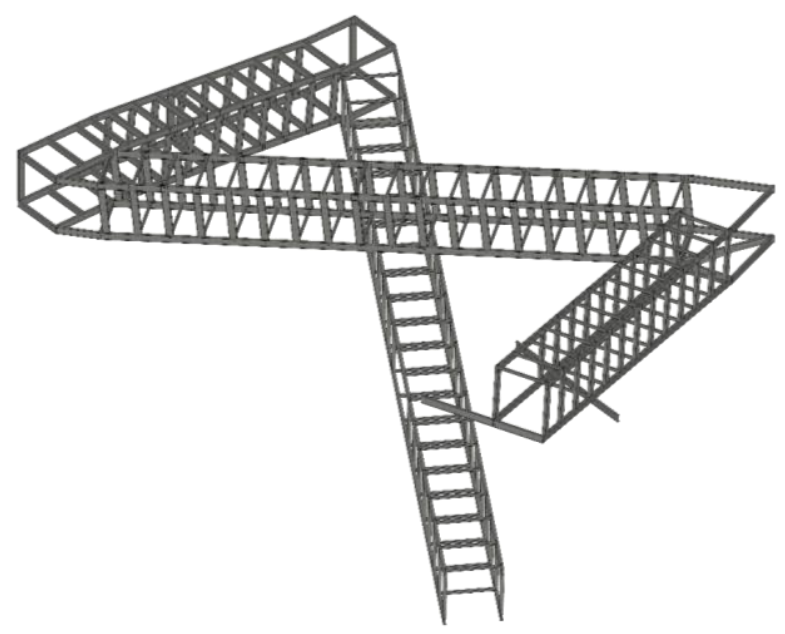

Gambar 7. Axonometri Struktur Sumber: Penulis, 2019 


\section{KESIMPULAN DAN SARAN \\ Kesimpulan}

Kelurahan Bungur merupakan kelurahan dengan karakter sebagai kawasan percetakan yang di dalamnya tentu terdapat tenaga kerja yang terampil. Tenaga kerja terampil yang ada memiliki tantangan dalam pekerjaannya yaitu mengandalkan fisik dan bekerja dengan durasi lebih lama daripada tenaga kerja terdidik. Untuk menciptakan sebuah third place maka harus dapat merespon karakter dan aktivitas yang terdapat di lingkungan tersebut. Oleh karena itu dalam mendesain tidak hanya tenaga kerja yang menjadi subjek tetapi warga Bungur lain juga menjadi subjek yang dipertimbangkan. Adanya pelatihan dan komunitas dalam bidang desain grafis bertujuan untuk memberikan nilai lebih kepada third place yang dirancang sehingga tidak hanya menjadi tempat berinteraksi sosial tetapi memberikan keterampilan dan juga berinteraksi dalam komunitas.

Proyek ini juga diharapkan mampu menjadi contoh bagaimana mendesain sebuah banguan yang menjadi third place bagi warga sekitar lingkungannya. Bangunan yang dapat menjadi tempat untuk memenuhi kebutuhan berinteraksi sosial bagi warganya dan juga memberikan nilai lebih bagi penggunanya sesuai dengan karakter lingkungannya.

\section{Saran}

Saran penulis adalah buatlah ruang ketiga yang menyenangkan di tempat perbatasan antara ruang pertama dan kedua, karena ruang ini sangat dibutuhkan di seluruh kehidupan manusia untuk mendukung jatidiri dan memotivasi agar tetap menjalankan aktivitasnya dengan maksimal.

\section{REFERENSI}

Anon., (2018). Fenomenologi: Pengertian, Contoh \& Metode Penelitian. [Online] Available at: http://sosiologis.com/fenomenologi

Architecture, D. O., (2016). The Commons / Department of Architecture. [Online] Available at: https://www.archdaily.com/800497/the-commons-department-ofarchitecture

Associés, D. C. \&., (2017). Media Library [Third-Place] in Thionville / Dominique Coulon \& associés. [Online]

Available at: https://www.archdaily.com/804682/media-library-third-place-in-thionvilledominique-coulon-and-associes?ad source=search\&ad medium=search result all

Herlambang, S., (2019). Open Society- Open City-Open Architecture, Jakarta: Fakultas Teknik Universitas Tarumanagara.

Jorgensen, D. L., (1986). Partisipan Observation. New Delhi: Sage Publication.

Monita, R., (2010). Heterotopia Pada Ruang Keseharian. pp. 6-18.

Oldenburg, R., (1999). The Great Good Place. New York: De Capo Press.

Sutanto, A., (2019). Architecture of The Third Place. 12 Juli.

Winata, S. (2019). Open Architecture - Architecture for The Third Place. Jakarta: Fakultas Teknik Untar. 
